\title{
ANALISIS PERBANDINGAN KINERJA KEUANGAN SEBELUM DAN SESUDAH MERGER-AKUISISI PADA PERUSAHAAN YANG TERDAFTAR DI BURSA EFEK INDONESIA (BEI) PERIODE 2015
}

\author{
Dimas Nur Setiantoso Putro \\ dimassubban@gmail.com \\ Universitas Ahmad Dahlan \\ Desta Rizky Kusuma \\ kusuma.desta@gmail.com \\ Universitas Ahmad Dahlan
}

\begin{abstract}
ABSTRAK
This study is entitled comparative analysis of financial performance before and after mergers-acquisitions in companies listed on the Indonesia Stock Exchange (IDX) Period 2015. The purpose of this study is to determine differences in financial performance before and after mergers and acquisitions of companies listed on the IDX measured using the ratio Total Asset Turnover, Return On Asset, and Net Profit Margin with Purposive Sampling techniques. This type of data source is secondary data taken from the official website of the Indonesia Stock Exchange (www.idx.co.id). The data taken is the data of financial statements and annual reports and sampling conducted with certain criteria. The population used in this study are companies that have merged and are listed on the Indonesia Stock Exchange, as many as 15 companies. The choice of location or place of research on the Indonesia Stock Exchange (IDX) through the official website www.idx.co.id (2019), the reason for choosing this location is because all data such as financial statements can be trusted. Based on the determined sample criteria from 15 merger-acquisition companies listed on the Indonesian Stock Exchange (IDX), 12 sample companies were obtained that met these criteria. The data analysis method used is descriptive analysis to analyze data by describing or describing the data that has been collected as it is without making conclusions that apply to the public or generalizations. Then the data collected was tested for normality and paired sample t-test with the help of the SPSS 22 application program.
\end{abstract}

Keywords: Financial Performance, Mergers-Acquisitions, TATO, NPM, ROA.

\begin{tabular}{l}
\hline PENDAHULUAN \\
Era globalisasi seperti saat ini \\
tidak menutup kemungkinan merubah \\
kehidupan saat ini menjadi lebih rasional. \\
Berlakunya pasar bebas membuat \\
persaingan dunia bisnis menjadi semakin \\
ketat. Berbagai upaya perlu dilakukan \\
oleh pelaku usaha atau industri untuk \\
menguasai pasar dan memenangkan \\
persaingan. Perusahaan-perusahaan harus \\
memiliki strategi yang tepat untuk dapat \\
meningkatkan eksistensinya dan mencapai
\end{tabular}

tujuan perusahaan dengan cara yang efisien dan efektif.

Menurut Husnan (2006), ekspansi terbagi menjadi dua macam, yaitu ekspansi internal dan ekspansi eksternal. Ekspansi internal adalah adanya divisidivisi di dalam perusahaan tumbuh dengan normal melalui capital budgeting perluasan usaha yang dapat dilakukan dengan cara menambah kapasitas, menambah unit produksi, divisi baru, dan menggabungkan dengan usaha yang telah ada (merger dan konsolidasi) atau 
membeli perusahaan yang telah ada (akuisisi). Sedangkan ekspansi eksternal dapat dilakukan dengan penggabungan usaha atau pengambil alihan usaha. Penelitian ini berfokus pada strategi ekspansi penggabungan usaha atau pengambil alihan usaha dengan suatu usaha yang telah ada (merger-akuisisi).

Pengembangan usaha dengan cara merger ini lebih mudah dan lebih cepat dijalankan karena tidak memerlukan riset pasar atau tes pasar yang harus mempersiapkan fasilitas diversifikasi produk. Strategi pengembangan ini memiliki kelebihan yaitu dapat memperbesar ukuran perusahaan dan menciptakan iklim persaingan yang lebih baik atau dengan kata lain dapat mengurangi persaingan.

Setiap perusahaan yang melakukan merger pasti memiliki tujuan tersendiri untuk kebaikan perusahaan itu sendiri. Tujuan mendasar perusahaan melakukan merger ialah sebagai pembuktian diri atas pertumbuhan dan pengembangan (ekspansi) aset dari perusahaan maupun penjualan sehingga dapat meningkatkan sinergi perusahaan (Utari, 2014). Sinergi mengacu pada optimalisasi peningkatan nilai dan manfaat yang dirasakan baik, bagi pihak pengambil alih dan yang diambil alih, serta berkaitan dengan optimalnya aktivitas optimalnya aktivitas operasional yang mengarah pada peningkatan output dan outcome dari implementasi konsep economic of scale (Kamaludin, 2015).

Penilaian tentang keberhasilan merger-akuisisi bergantung oleh beberapa hal, seperti penilaian akurat perusahaan target dan membuat perkiraan prospek kedepannya. Sinergi yang dihasilkan perusahaan merger-akuisisi dapat meningkatkan dalam jangka waktu yang panjang, apabila perusahaan menggunakan sumber daya dengan efektif. Hal yang harus diperhatikan dalam melakukan merger-akuisisi yaitu perlunya keputusan manajerial yang matang. Keputusan melakukan mergerakuisisikadang tidak terlepas dari masalah, bisa saja dengan biaya yang mahal, perusahaan tidak menghasilkan hasil yang diharapkan (Mamduh, 2014).

Penggabungan usaha pada suatu perusahaan dapat memberikan dampak keuntungan atau bahkan kerugian. Perusahaan dapat mengalami keuntungan atau kerugian dapat dilihat dari kinerja perusahaan setelah melakukan penggabungan usaha. Kinerja perusahaan merupakan sesuatu yang dihasilkan oleh suatu perusahaan dalam periode tertentu atas nilai perusahaan sesuai dengan tujuan perusaan. Ketika akan menentukan kinerja keuangan suatu perusahaan maka diperlukan rasio keungan untuk menilai suatu perusahaan yang telah melakukan penggabungan usaha/ merger-akuisisi. Rasio yang digunakan untuk menilai perusahaan yaitu likuiditas (current ratio), aktivitas (total asset turnover, foxed asset turnover), solvabilitas (debt to equity, debt to asset), profitabilitas (net to profit margin, return on asset, return on equity) serta rasio pasar (earning per share).

Secara teori dengan adanya merger-akuisisi perusahaan otomatis bertambah besar karena aset, kewajiban, dan ekuitas dari dua perusahaan digabung menjadi satu. Berdasarkan pengukuran akuntansi logisnya jika ukuran bertambah besar, kemudian bersinergi dengan aktivitas-aktivitas yang simultan, maka laba perusahaan akan semakin meningkat. Idealnya kinerja keuangan setelah merger-akuisisi jauh lebih baik dibandingkan dengan sebelum melakukan merger-akuisisi. 
Prisya (2017) mengemukakan bahwa untuk hasil analisis perbandingan yang diukur menggunakan rasio TATO menunjukkan adanya penurunan pada saat setelah melakukan mergerakuisisi baik satu tahun, dua tahun maupun tiga tahun setelahnya. Sedangkan pada rasio NPM mengalami kenaikan pada saat satu tahun setelah melakukan mergerakuisisi, dan mengalami penurunan berturutturut pada dua tahun hingga tiga tahun setelah merger-akuisisi. Selain itu, pada rasio ROA sedikit mengalami kenaikan pada saat satu tahun setelah merger-akuisisi. Namun, mengalami penurunan kinerja keuangan pada dua hingga tiga tahun berturut-turut.

Penurunan pada rasio TATO ternyata disebabkan oleh kurang efektifnya perusahaan dalam memanfaatkan atau mengelola aktiva yang tersedia di perusahaan. Hal ini merupakan hal yang perlu diperbaiki dan ditingkatkan untuk pengelolaan dan pemanfaatan aktiva agar aktivitas yang dijalankan perusahaan lebih baik dan tentunya kinerja keuangan akan semakin meningkat. Kemudian untuk Rasio NPM memiliki perbedaan yang signifikanpada satu tahun sesudah merger-aluisisi mengalami kenaikan dibanding sebelum merger-akuisisi. Hal ini terjadi karena setelah melakukan penggabungan usaha menyebabkan naiknya pendapatan perusahaan bagi pihak pengambil alih. Kemudian pada tahun kedua nilai rata-rata NPM mengalami penurunan dan mengalami nilai negatif pada tahun ketiga setelah merger-akuisisi. Hal tersebut disebabkan oleh laba perusahaan mengalami penurunan dikarenakan muncul pesaing baru dan adanya beban biaya pajak yang harus dibayarkan perusahaan.Selain itu, untuk nilai ratarata ROA sedikit mengalami kenaikan yang disebabkan aktiva perusahaan semakin bertambah, akan tetapi laba bersih perusahaan yang diperoleh mengalami kenaikan yang tidak terlalu tinggi. Kemudian nilai rata-rata ROA mengalami penurunan pada tahun kedua hingga ketiga setelah merger-akuisisi. Penurunan tersebut disebabkan oleh peningkatan aktiva yang tidak diiringi oleh peningkatan laba bersih. Laba bersih tersebut mengalami penurunan disebabkan penjualan tidak terlalu besar sedangkan beban perusahaan yang harus ditanggung meningkat.

Berdasarkan penelitian terdahulu, penelitian ini bertujuan untuk mengetahui kinerja keuangan perusahaan sebelum dan sesudah mergerakuisisi yang ditinjau dari rasio profitabilitas dan rasio aktivitas. Rasio profitabilitas meliputi Net to Profit Margin (NPM) dan Return on Asset (ROA), serta rasio aktivitas yaitu menggunakan Total Asset Turn Over (TATO).

\section{REVIEW LITERATUR DAN HIPOTESIS}

\section{Landasan Teoei}

1. Pengembangan Usaha

Persaingan yang ketat membuat perusahaan harus memiliki strategi bisnis yang bertujuan untuk mempertahankan kelangsungan hidup perusahaan serta mengembangkan usaha. Strategi bisnis menciptakan suatu keputusan strategik yang merupakan pilihan alternatif untuk mencapai tujuan perusahaan. Salah satu keputusan strategik yaitu keputusan investasi yang berkaitan dengan pengembangan usaha (Sutrisno, 2011).

\section{Merger}

Merger merupakan penggabungan dua perusahaan atau lebih menjadi satu perusahaan, dimana perusahaan 
pengambil alih (acquiring company) tetap memiliki identitas, sedangkan perusahaan diambil alih (target company) menghentikan kegiatan usahanya, dan meleburkan badan hukumnya (Tampubolon, 2013).

\section{Akuisisi}

Akuisisi merupakan pengambilaliahan suatu perusahaan oleh perusahaan lain dengan tetap mempertahankan identitas perusahaan yang diambil alih. Perusahaan pengambil alih disebut acquiring company, sedangkan perusahaan yang diambil alih disebut dengan perusahaan target (target company) (Sitanggang, 2013).

Peng dan Vijay (2012) telah menemukan adanya perbaikan kinerja jangka pendek dan jangka panjang selama periode pasca akuisisi. Jianyu et al (2009) dan Mukiyanto (2005) dalam penelitiannya telah menemukan adanya kenaikan abnormal return yang signifikan setelah akuisisi. Selain itu, pengujian yang dilakukan oleh Kurniawati (2011) tentang pengaruh pengumuman merger-akuisisi terhadap return saham perusahaan akuisitor telah menunjukkan bahwa terdapat perbedaan yang signifikan abnormal return sebelum dan sesudah pengumuman merger-akuisisi pada perusahaan.

\section{Kinerja Keuangan}

Harahap (2008) adalah angka yang diperoleh dari hasil perbandingan antara suatu pos laporan keuangan dengan pos lainnya yang mempunyai hubungan yang relevan dan siginifikan (berarti), misalnya: antara hutang dengan modal, antara kas dengan total aset, antara harga pokok produksi dengan total penjualan. Sedangkan pendapat lain menyatakan bahwa analisis rasio keuangan adalah suatu teknik analisis untuk mengetahui pospos tertentu dalam neraca atau laporan laba rugi secara individual atau kombinasi dari kedua laporan tersebut (Munawir, 2007).

Analisis rasio keuangan dapat memberikan petunjuk dan gejala-gejala serta informasi keuangan lainnya mengenai keadaan keuangan suatu perusahaan.

\section{Rasio Profitabilitas}

Rasio Profitabilitas merupakan rasio yang digunakan untuk mengukur kemampuan perusahaan dalam menghasilkan laba dari aktivitas normal bisnisnya (Hery, 2015)

a. Net profit margin atau marjin laba bersih merupakan rasio yang digunakan untuk mengukur besarnya presentase laba bersih atas penjualan bersih (Hery, 2015)

b. Gross profit margin atau marjin laba kotor merupakan rasio yang digunakan untuk mengukur besarnya prosentase laba kotor atas penjualan bersih (Hery, 2015)

\section{Rasio Aktivitas}

Rasio aktivitas merupakan rasio yang digunakan untuk mengukur efektivitas perusahaan dalam menggunakan aset yang dimilikinya, termasuk untuk mengukur tingkat efisiensi perusahaan dalam memanfaatkan sumber daya yang ada (Hery, 2015).

a. Total Asset Turn Over atau perputaran aktiva merupakan rasio yang digunakan untuk mengukur kefektifan total aset yang dimiliki perusahaan dalam menghasilkan penjualan, atau dengan kata lain untuk mengukur beberapa jumlah penjualan yang akan dihasilkan dari setiap rupiah dana yang tertanam dalam total aset (Hery, 2015). 
b. Fixed asset Turn Over atau perputaran aset tetap merupakan rasio yang digunakan untuk mengukur kefektifan aset tetap yang dimiliki perusahaan dalam menghasilkan penjualan, atau dengan kata lain untuk mengukur seberapa efektif kapasitas aset tetap turut berkontribusi menciptakan penjualan (Hery, 2015).

\section{Rasio Rasio Likuiditas}

Rasio Likuiditas merupakan indikator kemampuan perusahaan untuk membayar atau melunasi kewajiban-kewajiban finansialnya pada saat jatuh tempo dengan mempergunakan aktiva lancar yang bersedia (Harjito, 2005).

a. Current ratio atau rasio lancar merupakan rasio yang digunakan untuk mengukur kemampuan perusahaan dalam memenuhi kewajiban jangka pendeknya yang segera jatuh tempo dengan menggunakan total aset lancar yang tersedia (Hery, 2015).

b. Cash Ratio atau rasio kas merupakan rasio yang digunakan untuk mengukur seberapa besar uang kas atau setara kas yang tersedia untuk membayar utang jangka pendek (Hery, 2015).

\section{Rasio Solvabilitas}

Rasio solvabilitas merupakan rasio yang digunakan untuk mengukur sejauh mana aset perusahaan dibiayai dengan utang (Hery, 2015).

a. Debt ratio atau rasio utang merupakan rasio antara total hutang (total debt) dengan total aset (total aset) yang dinyatakan dalam persentase (Hery, 2015).

b. Debt to equity ratio atau rasio utang terhadap modal merupakan rasio yang digunakan untuk mengukur besarnya proporsi utang terhadap modal (Hery, 2015).

\section{Penelitian Terdahulu}

Annisa (2010), dalam penelitiannya menghasilkan bukti bahwa kinerja keuangan yang diproksikan dengan total asset turnover (TATO), net profit margin (NPV), dan return on asset (ROA) mengalami kenaikan yang berbeda-beda sebelum maupun sesudah merger-akuisisi. TATO mengalami kenaikan sesudah merger-akuisisi dibandingkan sebelum merger-akuisisi, sedangkan NPM dan ROA mengalami penurunan sesudah merger-akuisisi.

Prisya dan Nila (2017) mengemukakan bahwa untuk hasil analisis perbandingan yang diukur menggunakan rasio TATO menunjukkan adanya penurunan pada saat setelah melakukan merger-akuisisi baik satu tahun, dua tahun maupun tiga tahun setelahnya. Sedangkan pada rasio NPM mengalami kenaikan pada saat satu tahun setelah melakukan mergerakuisisi, dan mengalami penurunan berturut-turut pada dua tahun hingga tiga tahun setelah merger-akuisisi. Selain itu, pada rasio ROA sedikit mengalami kenaikan pada saat satu tahun setelah merger-akuisisi. Namun, mengalami penurunan kinerja keuangan pada dua hingga tiga tahun berturut-turut.

\section{Hipotesis}

H1 : Terdapat perbedaan kinerja keuangan yang di ukur dengan rasio total asset turn over sebelum dan sesudah merger-akuisisi.

$\mathrm{H} 2$ : Terdapat perbedaan kinerja keuangan yang di ukur dengan rasio return on asset sebelum dan sesudah mergerakuisisi.

H3 : Terdapat perbedaan kinerja keuangan yang di ukur dengan rasio net profit margin (NPM) sebelum dan sesudah merger-akuisisi. 


\section{METODE PENELITIAN}

\section{Populasi dan Sampel}

Populasi adalah wilayah generalisasi yang terdiri dari objek-objek yang mempunyai kualitas dan karaktersitik tertentu yang ditetapkan oleh peneliti untuk dipelajari dan kemudian ditarik kesimpulan (Sugiyono, 2006). Populasi yang digunakan dalam penelitian ini Perusahan yang melakukan mergerakuisisi dan terdaftar di Bursa Efek Indonesia, yaitu sebanyak 15 perusahaan.

Objek penelitian ini adalah perusahaan yang melakukan mergerakuisisi. Dalam penelitian ini pengambilan sampel yang dilakukan secara non probability sampling, yaitu dengan pendekatan purposive sampling.

\section{Jenis Sumber Data}

Jenis data yang digunakan dalam penelitian ini adalah sumber data sekunder yang diambil dari website resmi Bursa Efek Indonesia (www.idx.co.id). Data yang diambil adalah data laporan keuangan dan annual report.

\section{Teknik Pengumpulan Data}

Metode pengumpulan data yang digunakan dalam penelitian ini adalah metode dokumentasi, yaitu dengan cara mengumpulkan data yang berbentuk annual report dan laporan keuangan. Datadata perusahaan tersebut diperoleh dari Bursa Efek Indonesia (www.idx.ac.id). Jangka waktu penelitiannya yaitu, tahun 2014-2017 dengan tahun merger-akuisisi 2015. Relevannya tahun pengamatannya adalah 2014-2016. Namun, karena dikhawatirkan masing-masing perusahaan memiliki waktu merger-akuisisi yang berbeda-beda, maka untuk satu tahun sesudah merger-akuisisi dihitung hingga tahun 2017 untuk mengantisipasi waktu terjadinya merger-akuisisi diawal-awal bulan pada tahun 2016 .

\section{Definisi Operasional}

Kinerja keuangan didefinisikan sebagai prestasi manajemen keuangan untuk mencapai tujuan perusahaan yaitu menghasilkan keuntungan dan meningkatkan nilai perusahaan. Kinerja keuangan dalam penelitian ini di ukur dengan menggunakan rasio aktivitas dan profitabilitas.

1. Rasio aktivitas menunjukkan kemampuan dana yang tertanam dalam keseluruhan aktiva berputar dalam suatu periode tertentu atau kemampuan modal yang di investasikan untuk menghasilkan revenue. Pengukuran rasio aktivitas disini menggunakan total asset turnover.

Perputaran Aktiva $=\frac{\text { Penjualan bersih }}{\text { Total Aktiva }}$

2. Rasio profitabilitas mengukur seberapa besar kemampuan perusahaan memperoleh laba baik dalam hubungannya dengan penjualan, aset maupun laba bagi modal sendiri. Pengukuran rasio profitabilitas ini menggunakan net profit margin dan return on asset.

a. Net Profit Margin adalah salah satu rasio yang digunakan untuk menilai presentasi laba atas setiap penjualan setelah dikurangkan dengan adanyaadanya biaya-biaya dan pengeluaran lainnya (Syamsudin, 2011).

$$
N P M=\frac{\text { Keuntungan Netto sesudah Pajak }}{\text { Penjualan Netto }}
$$

b. Return on Asset adalah alat ukur atau rasio yang biasa digunakan untuk mengukur keuntungan yang di dapatkan dari setiap nilai rupiah aset dalam perusahaan (Hery, 2015). 


$$
R O A=\frac{\text { EBIT }}{\text { Jumlah Aktiva }}
$$

\section{Uji Instrumen}

\section{a. Statistik Deskriptif}

Statistik Deskriptif adalah statistik yang digunakan untuk menganalisa data dengan cara mendeskripsikan atau menggambarkan data yang telah terkumpul sebagaimana adanya tanpa membuat kesimpulan yang berlaku untuk umum atau generalisasi (Sugiyono, 2006).

\section{b. Uji Normalitas}

Uji Normalitas adalah suatu uji yang dilakukan untuk mengetahui sebuah model regresi yaitu variabel dependen, variabel independent, atau keduanya mempunyai distribusi normal ataukah tidak. Model regresi yang baik adalah distribusi data normal atau mendekati normal. Dalam rangka mendeteksi normalitas dapat melihat grafik normal P-P Plot of Regression Standardized Residual. Deteksi dengan melihat penyebaran data pada sumbu diagonal dari grafik (Ghozali, 2013).

Uji normalitas dilakukan dengan menggunakan Software SPSS for Windows. Sebelum hipotesis diuji, maka akan dilakukan terlebih dahulu uji normalitas data Kolmogorov Smirnov untuk melihat apakah data berdistribusi secara normal atau tidak. Apabila nilai signifikansinya lebih dari 0,05 maka data tersebut berdistribusi normal. Akan tetapi, apabila nilai signifikansinya kurang dari 0,05 maka data tersebut tidak normal. Jika data berdistribusi normal, maka pengujian hipotesis menggunakan paired sample t-test, tapi jika data tidak berdistribusi normal, maka pengujian hipotesis menggunakan uji data berperingkat Wilcoxon.

\section{Teknik Analisis Data}

Analisis rasio keuangan digunakan untuk menganalisis hasil keputusan merger-akuisisi terhadap kondisi keuangan berdasarkan rasio total asset turnover, net profit margin dan return on asset dibandingkan dengan rasio sebelum merger-akuisisi. Langkah pertama yang dilakukan adalah menghitung masingmasing rasio keuangan yang sudah ditetapkan sebagai variabel penelitian.

Hasil perhitungan rasio-rasio ini selanjutnya digunakan sebagai data dalam pengujian statistik. Pengujian statistik dalam penelitian ini menggunakan alat uji paired sample t-test untuk varian data yang berdistribusi normal dan alat uji wilcoxon signed rank test untuk varian yang tidak berdistribusi normal.

\section{Uji Hipotesis}

Hipotesis diuji dengan menggunakan alat statistik paired sample t-test. Langkah-langkah uji t, yaitu:

a. Melakukan perhitungan selisih (d) antara pengamatan sebelum dan setelah.

b. Melakukan perhitungan d rata-rata, kemudian kuadratkan selisish tersebut dan menghitung total selisih kuadrat.

c. Mencari standar deviasi (sd) dengan rumus:

$$
\mathrm{S}=\sqrt{ } \sqrt{\sum \frac{\sqrt{X i-X 2}}{n-i}}
$$

d. Menghitung $t$ dengan rumus:

$$
\mathrm{t}=\frac{d}{s / \sqrt{n}}
$$

e. Kriteria pengambilan keputusan pengujian hipotesis adalah jika probabilitas > 0,05, maka Ha ditolak dan jika probabilitas < 0,05 maka Ha diterima. 
Uji paired sample t-test digunakan untuk menguji hipotesis guna membuktikan apakah terdapat perbedaan kinerja keuangan jika dilihat dari segi rasio aktivitas yang diukur dengan total asset turnover dan rasio profitabilitas yang diukur dengan net profit margin dan return on asset pada periode sebelum dan setelah merger-akuisisi. Kemudian pengujian hipotesis dalam penelitian ini dapat diamati dengan cara, yaitu:

a. H1 diterima, apabila probabilitas < 0,05; dan H1 ditolak apabila probabilitas > 0,05. Artinya ada perbedaan kinerja keuangan yang diukur melalui rasio aktivitas total asset turnover (TATO) setelah melakukan merger-akuisisi.

b. H2 diterima, apabila probabilitas < 0,05; dan $\mathrm{H} 2$ ditolak apabila probabilitas > 0,05. Artinya ada perbedaan kinerja keuangan yang diukur melalui rasio profitabilitas return on asset (ROA) setelah melakukan merger-akuisisi.

c. H3 diterima, apabila probabilitas < 0,05; dan $\mathrm{H} 3$ ditolak apabila probabilitas > 0,05. Artinya ada perbedaan kinerja keuangan yang diukur melalui rasio profitabilitas net profit margin setelah melakukan merger-akuisisi.

\section{HASIL PENELITIAN DAN PEMBAHASAN}

\section{Hasil Penelitian}

Berdasarkan hasil pengolahan data, menghasilkan nilai rata-rata Total Asset Turnover untuk periode 1 tahun sebelum merger-akuisisi sebesar 0,53 dengan nilai standar deviasi sebesar 0,81 . Hasil tersebut menunjukkan bahwa, standar deviasi lebih besar dibanding nilai rata-rata maka hal ini menunjukkan adanya kesenjangan yang besar antara nilai minimum dengan nilai maksimum.

Untuk hasil nilai rata-rata total asset turnover 1 tahun sesudah merger-akuisisi sebesar 0,52 dengan nilai standar deviasi sebesar 0,88 . Hasil tersebut menunjukkan bahwa, standar deviasi lebih besar dibanding nilai rata-rata maka hal ini menunjukkan adanya kesenjangan yang besar antara nilai minimum dengan nilai maksimum. Hasil tersebut apabila digunakan untuk perbandingan rata-rata total asset turnover antara sebelum merger-akuisisi dengan sesudah mergerakuisisi, maka dapat ditarik kesimpulan bahwa pada rasio tersebut telah mengalami penurunan total asset turnover sesudah melakukan merger-akuisisi.

Nilai rata-rata return on asset untuk periode 1 tahun sebelum merger-akuisisi sebesar 9,06 dengan nilai standar deviasi sebesar 16,91. Hasil tersebut menunjukkan bahwa, standar deviasi lebih besar dibanding nilai rata-rata maka hal ini menunjukkan adanya kesenjangan yang besar antara nilai minimum dengan nilai maksimum.

Untuk hasil nilai rata-rata return on asset 1 tahun sesudah merger-akuisisi sebesar 2,00 dengan nilai standar deviasi sebesar 7,69. Hasil tersebut menunjukkan bahwa, standar deviasi lebih besar dibanding nilai rata-rata maka hal ini menunjukkan adanya kesenjangan yang besar antara nilai minimum dengan nilai maksimum. Hasil tersebut apabila digunakan untuk perbandingan rata-rata total asset turnover antara sebelum merger-akuisisi dengan sesudah mergerakuisisi, maka dapat ditarik kesimpulan bahwa pada rasio tersebut telah mengalami penurunan total asset turnover sesudah melakukan merger-akuisisi. 
Nilai rata-rata net profit margin untuk periode 1 tahun sebelum mergerakuisisi sebesar 23,22 dengan nilai standar deviasi sebesar 29,87. Hasil tersebut menunjukkan bahwa, standar deviasi lebih besar dibanding nilai rata-rata maka hal ini menunjukkan adanya kesenjangan yang besar antara nilai minimum dengan nilai maksimum.

Untuk hasil nilai rata-rata net profit margin 1 tahun sesudah merger-akuisisi sebesar 19,06 dengan nilai standar deviasi sebesar 101,88. Hasil tersebut menunjukkan bahwa, standar deviasi lebih besar dibanding nilai rata-rata maka hal ini menunjukkan adanya kesenjangan yang besar antara nilai minimum dengan nilai maksimum. Hasil tersebut apabila digunakan untuk perbandingan rata-rata total asset turnover antara sebelum merger-akuisisi dengan sesudah mergerakuisisi, maka dapat ditarik kesimpulan bahwa pada rasio tersebut telah mengalami penurunan total asset turnover sesudah melakukan merger-akuisisi.

Hasil analisis pada rasio aktivitas menggunakan total asset turnover (TATO) yang membandingkan kinerja keuangan antara 1 tahun sebelum merger-akuisisi dengan 1 tahun sesudah merger-akuisisi dengan jumlah sample 12 perusahaan yang terdaftar di Bursa Efek Indonesia yang melakukan merger-akuisisi didapatkan hasil pada rasio TATO berupa nilai signifikansi sebesar 0,69. Kemudian hasil dari uji hipotesis $\mathrm{H}_{1}$ ditolak karena TATO tidak berbeda secara signifikan antara sebelum dan sesudah merger-akuisisi. Artinya, dari hasil ini dapat diambil kesimpulan bahwa fenomena mergerakuisisi ini tidak berpengaruh secara signifikan terhadap rasio aktivitas perusahaan dan terjadi penurunan jika dilihat dari rata-rata sesudah melakukan merger-akuisisi. Perlu diketahui dengan ditolaknya hipotesis tersebut fenomena merger-akuisisi tidak berpengaruh terhadap aktivitas perusahaan terutama pada perputaran aset untuk menghasilkan pendapatan dan jika dilihat dari rata-rata dalam 1 tahun sesudah merger-akuisisi perusahaan mengalami penurunan maka dibutuhkan proses yang lebih panjang untuk mengoptimalkan tujuan dari dilakukannya penggabungan usaha atau merger-akuisisi.

Hasil analisis pada rasio aktivitas menggunakan return on asset (ROA) yang membandingkan kinerja keuangan antara 1 tahun sebelum merger-akuisisi dengan 1 tahun sesudah merger-akuisisi dengan jumlah sample 12 perusahaan yang terdaftar di Bursa Efek Indonesia yang melakukan merger-akuisisi didapatkan hasil pada rasio ROA berupa nilai signifikansi sebesar 0,27. Kemudian hasil dari uji hipotesis $\mathrm{H}_{2}$ ditolak karena ROA tidak berbeda secara signifikan antara sebelum dan sesudah merger-akuisisi. Artinya, dari hasil ini dapat diambil kesimpulan bahwa fenomena mergerakuisisi ini tidak berpengaruh secara signifikan terhadap rasio profitabilitas perusahaan dan terjadi penurunan jika dilihat dari rata-rata sesudah melakukan merger-akuisisi. Perlu diketahui dengan ditolaknya hipotesis tersebut fenomena merger-akuisisi tidak berpengaruh terhadap profitabilitas perusahaan terutama pada keuantungan yang didapat pada setiap nilai rupiah aset dalam perusahaan dan jika dilihat dari rata-rata dalam 1 tahun sesudah merger-akuisisi perusahaan mengalami penurunan maka dibutuhkan proses yang lebih panjang untuk mengoptimalkan tujuan dari dilakukannya penggabungan usaha atau merger-akuisisi.

$$
\text { Hasil analisis pada rasio }
$$

profitabilitas menggunakan net profit margin (NPM) yang membandingkan 
kinerja keuangan antara 1 tahun sebelum merger-akuisisi dengan 1 tahun sesudah merger-akuisisi dengan jumlah sample 12 perusahaan yang terdaftar di Bursa Efek Indonesia yang melakukan merger-akuisisi didapatkan hasil pada rasio NPM berupa nilai signifikansi sebesar 0,86. Kemudian hasil dari uji hipotesis $\mathrm{H}_{3}$ ditolak karena NPM tidak berbeda secara signifikan antara sebelum dan sesudah mergerakuisisi. Artinya, dari hasil ini dapat diambil kesimpulan bahwa fenomena merger-akuisisi ini tidak berpengaruh secara signifikan terhadap rasio profitabilitas perusahaan dan terjadi penurunan jika dilihat dari rata-rata sesudah melakukan merger-akuisisi. Perlu diketahui dengan ditolaknya hipotesis tersebut fenomena merger-akuisisi tidak berpengaruh terhadap profitabilitas perusahaan terutama pada presentasi laba atas setiap penjualan setelah dikurangkan dengan biaya-biaya dan jika dilihat dari rata-rata dalam 1 tahun sesudah mergerakuisisi perusahaan mengalami reaksi negatif yaitu terjadi penurunan pada nilai rata-rata maka dibutuhkan proses yang lebih panjang untuk mengoptimalkan tujuan dari dilakukannya penggabungan usaha atau merger-akuisisi.

\section{Pembahasan}

Penelitian ini menganalisis perbandingan antara satu tahun sebelum dan satu tahun sesudah merger-akuisisi pada perusahaan yang terdaftar di Bursa Efek Indonesia (BEI) dan terdapat 12 kasus merger-akuisisi. Jangka waktu penelitian yaitu tahun 2014-2017 dengan tahun merger-akuisisi yaitu pada 2015 . Relevannya tahun pengamatannya adalah 2014-2016. Namun, karena dikhawatirkan masing-masing perusahaan memiliki waktu merger-akuisisi yang berbeda-beda, maka untuk satu tahun sesudah mergerakuisisi dibulatkan pada tahun 2017.

Hasil analisis perbandingan kinerja keuangan antara satu tahun sebelum dan satu tahun sesudah merger-akuisisi yang di uji dengan menggunakan alat statistik Paired Sample t-test tidak mengalami perbedaan atau tidak signifikan. Berdasarkan hasil pengujian pada penelitian ini didapatkan hasil bahwa rasio total asset turnover (TATO) tidak mengalami perbedaan atau tidak signifikan. Menurut Salwa (2018) menyatakan hasil penelitiannya tentang pengaruh merger-akuissisi terhadap kinerja perusahaan yang menunjukan hasil yang tidak siignifikan pada penelitian untuk rasio total asset turnover (TATO) dengan rentang waktu pengamatan 2012-2014. Hal ini menunjukkan, bahwa jika jangka waktu penelitian ini masih tergolong pendek, maka dibutuhkan proses yang lebih panjang untuk mengoptimalkan tujuan dari dilakukannya penggabungan usaha atau merger-akuisisi.

Adapun hasil pengujian pada rasio return on asset (ROA) berdasarkan hasil pengujian pada penelitian ini didapatkan hasil bahwa rasio return on asset (ROA) tidak mengalami perbedaan atau tidak signifikan. Payamta (2000) menemukan tidak adanya perbedaan kinerja yang siginifikan pada rasio keuangan return on asset (ROA) dari hasil perbandingan baik sebelum maupun sesudah merger-akuisisi. Kemudian Payamta menambahkan, bahwa ada kemungkinan terjadi tindakan window dressing atas pelaporan keuangan perusahaan pengakuisisi untuk tahun-tahun sebelum merger-akuisisi dengan menunjukkan kemampuan yang lebih baik sehingga menarik bagi perusahaan target. Hal ini menunjukkan, bahwa selain pengaruh jangka waktu pengamatan yang relatif pendek, ternyata masih ada 
kemungkinan faktor pengaruh dari tindakan window dressing.

\section{KESIMPULAN DAN SARAN}

\section{Kesimpulan}

Setelah dilakukan penelitian analisis perbandingan kinerja keuangan satu tahun sebelum dan satu tahun sesudah mergerakuisisi dengan cara melakukan pengujian pada beberapa variable yang digunakan dalam penelitian ini mulai dari variabel total asset turnover (TATO), return on asset (ROA), dan net profit margin (NPM) maka berdasarkan hasil penelitian yang telah dilakukan dapat disimpulkan sebagai berikut:

1. Berdasarkan hasil pengujian pada perusahaan yang melakukan mergerakuisisi dalam penelitian ini, setelah dilakukan analisis perbandingan sebelum melakukan merger-akuisisi telah menunjukkan hasil tidak adanya perbedaan yang signifikan pada kinerja keuangan rasio total asset turnover (TATO) sesudah melakukan mergerakuisisi.

2. Berdasarkan hasil pengujian pada perusahaan yang melakukan mergerakuisisi dalam penelitian ini, setelah dilakukan analisis perbandingan sebelum melakukan merger-akuisisi telah menunjukkan hasil tidak adanya perbedaan yang signifikan pada kinerja keuangan rasio return on asset (ROA) sesudah melakukan merger-akuisisi.

3. Berdasarkan hasil pengujian pada perusahaan yang melakukan mergerakuisisi dalam penelitian ini, setelah dilakukan analisis perbandingan sebelum melakukan merger-akuisisi telah menunjukkan hasil tidak adanya perbedaan yang signifikan pada kinerja keuangan rasio net profit margin (NPM) sesudah melakukan mergerakuisisi.

Berdasarkan hasil penelitian diatas dengan ini dapat diambil kesimpulan bahwa kegiatan merger-akuisisi tidak selamanya memberikan dampak yang positif terhadap kinerja keuangan perusahaan. Hal tersebut dapat dibuktikan dengan beberapa variabel yang tidak mengalami perubahan perbedaan yang signifikan oleh kegiatan merger-akuisisi.

Peristiwa seperti ini bisa saja terjadi dikarenakan perusahaan mengalami kesulitan dalam bersinergi terutama ketika ada permasalahan seperti mahalnya biaya untuk melakukan merger-akuisisi. kemudian faktor Corporate Culture, dimana permasalahan ini terjadi pada sumber daya manusia yang dipekerjakan, baik sumber daya manusia perusahaan pengakuisisi maupun perusahaan yang diakuisisi sehingga membutuhkan waktu lebih dari 3 tahun untuk dapat bersinergi dan berkolaborasi untuk dapat memberikan dampak positif terhadap kinerja keuangan perusahaan. Selain itu, juga ada kemungkinan terjadinya windows dressing pada pelaporan keuangan perusahaan pengakuisisi untuk tahun-tahun sebelum merger-akuisisi dengan menunjukkan kemampuan yang lebih baik sehingga menarik bagi perusahaan target.

\section{Saran}

Berdasarkan hasil kesimpulan di atas maka peneliti menyarankan:

1. Bagi Praktisi

Bagi para praktisi manajemen perusahaan yang akan mengambil keputusan untuk melakukan mergerakuisisi, lebih baik melakukan pengamatan dan pertimbangan yang cukup matang. Karena hasil dari penelitian ini menunjukkan bahwa, peristiwa merger-akuisisi secara garis 
besar tidak menunjukkan perbedaan yang signifikan pada kinerja keuangan perusahaan.

2. Bagi Akademisi

Untuk para akademisi peneliti yang akan datang, sebaiknya menambah jumlah rasio-rasio dari rasio aktivitas seperti misalnya, rasio total asset turn over dan rasio fixed asset turnove; rasio profitabilitas seperti misalnya rasio net profit margin dan gross profir margin; rasio likuiditas seperti misalnya current ratio (rasio lancar), dan cash ratio (rasio kas); dan rasio solvabilitas seperti misalnya debt ratio (rasio utang) dan debt to equity ratio (rasio utang terhadap modal). Selain itu, menambah jangka waktu laporan keuangan yang akan digunakan untuk menghitung kineja keuangan sebelum dan sesudah merger-akuisisi sehingga kualitas penelitian tersebut akan menjadi lebih baik.

3. Bagi Penyelenggara Kebijakan

Berdasarkan hasil penelitian ini, pengembangan usaha dengan cara penggabungan usaha, yaitu mergerakuisisi secara garis besar saat ini kurang menunjukkan peningkatan yang signifikan pada kinerja keuangan perusahaan. Sehingga hasil penelitian ini dapat dijadikan referensi untuk membuat kebijakan yang lebih kuat untuk mengatur persaingan usaha dalam dunia bisnis di Indonesia.

\section{DAFTAR PUSTAKA}

Annisa, Meta. (2010). Analisis Manajemen

Laba dan Kinerja Keuangan Perusahaan Pengakuisisi Sebelum dan Sesudah Merger dan Akuisisi yang Terdaftar di Bursa Efek Indonesia Tahun 2008-2009. Skripsi (Desember), hal 21.
Gozali, Imam. (2013). Aplikasi Analisis Multivariate dengan Program SPSS. Edisi Ketujuh. Semarang: Badan Penerbit Universitas Diponegoro.

Harahap, Sofyan Syafri. (2008). Analisis Kritis Atas Laporan Keuangan." Jakarta: Raja Grafindo Persada.

Harjito, Agus dan Martono. (2005). Manajemen Keuangan Perusahaan. Edisi Kedua, Cetakan Kelima, Yogyakarta: Penerbit EKONISIA.

Hery. (2015). Analisis Laporan Keuangan. Yogyakarta: CAPS.

Husnan, Suad dan Enny Pudjiastuti. (2006). Dasar-Ddasar Manajemen Keuangan. Edisi Kelima. Yogyakarta: UPP STIM YKPN

Jianyu Ma, Jose A. Pagan, and Yun Chu. (2009). Abnormal Returns to Mergers and Acquisitions in Ten Asian Stock Markets. International Jurnal of Economics and Finance. 14 (3), pp: 235-250.

Kamaludin, dkk. (2015). Restrukturisasi merger dan akuisisi. Bandung: Bandar Maju

Kurniawati, Rina. (2011). Pengaruh Pengumuman Merger dan Akuisisi terhadap Return Saham Perusahaan Akuisitor yang Terdaftar di Bursa Efek Indonesia Periode 2005-2008. Jurnal Manajemen Bisnis (FOKUS), 1 (1), pp: 1-13.

Mamduh, dkk. (2014). Analisa Laporan Keuangan. Edisi Kedua. Yogyakarta: UPP STIM YKPN.

Mukiyanto, Ali. (2005). Pengaruh Faktorfaktor Akuisisi terhadap Abnormal Return (Studi pada Perusahaan Akuisitor yang Terdaftar di BEJ antara tahun 1992-1997). Jurnal Siasat Bisnis., 1(10), pp: 57-72. 
Munawir. (2007). Analisis Laporan Keuangan. Yogyakarta: Edisi Empat, Liberty.

Payamta. (2000). Analisis Pengaruh Keputusan Merger dan Akuisisi terhadap Perubahan Kinerja Perusahaan Publik di Indonesia". Disampaikan pada Simposium Nasional Akuntansi Indonesia IV.

Peng, Cheng Zhu and Vijay Jog. (2012). Impact on Target Firm Risk-Return Characteristics of Domestic and Cross-Border Merger and Acquisitions in Emerging Markets. Emerging Markets Finance \& Trade, 48 (4), pp: 79-101.

Prisya, Esterlina dan Nila Nuzula F. (2017). Analisis Kinerja Keuangan Sebelum dan Sesudah Merger dan Akuisisi. Malang. Jurnal Administrasi Bisnis (Juni), hal 46-47 Salwa, Fananni. (2018). Analisis Pengaruh Merger Dan Akuisisi Terhadap Kinerja Perusahaan Go Public Di Bursa Efek Indonesia. Yogyakarta: Universitas Islam Indonesia.

Sitanggang, J.P. (2013). Manajemen Keuangan Perusahaan Lanjutan. Jakarta: Mitra Wacana Media.

Sugiyono. (2006). Metode Penelitian Kuantitatif, Kualitatif dan $R \& D$. Bandung: Alfabeta.

Sutrisno. (2009). Manajemen Keuangan

Teori, Konsep dan Aplikasi. Yogyakarta: Ekonisia.

Syamsuddin, Lukman. (2011). Manajemen Keuangan Perusahaan. Jakarta: Rajawali Pers.

Tampubolon, Manahan P. (2013). Manajemen Keuangan. Jakarta: Mitra Wacana Media.

Utari, Dewi, dkk. (2014). Manajemen Keuangan: Kajian Praktik dan Teori dalam Mengelola Keuangan
Perusahaan Organisasi Perusahaan. Jakarta: Mitra Wacana Media. 